\title{
A Children's Rights Perspective to Ruiz Zambrano and Chavez-Vilchez: An Examination in Light of Theory, Practice and Child Development Research
}

\author{
Ellen Nissen, LL.M. \\ $\mathrm{PhD}$ Researcher, Centre for Migration Law, Radboud University, \\ Nijmegen, The Netherlands \\ E.Nissen@jur.ru.nl
}

\begin{abstract}
This contribution demonstrates that the CJEU cases Ruiz Zambrano and Chavez-Vilchez are particularly significant from a children's rights perspective. The article connects these two judgments and their implementation in the national Dutch context, with three commonplace themes from children's rights literature; (1) the child as an equal bearer of rights, (2) the child as a distinct bearer of rights, and (3) the important role of developmental research. This perspective shows that the approach adopted by the CJEU with regard to the EU citizen child is paradigm shifting, as it breaks with dominant approaches in fundamental rights law and immigration law which historically place parental rights front and centre. The contribution demonstrates that the importance of this shift cannot be underestimated, because it provides the contested notions of children's rights and the Convention on the Right of the Child (CRC) with both legitimacy and meaning.
\end{abstract}

\section{Keywords}

best interests of the child - children's rights - EU citizenship - right to respect for family life - children's rights theory 
When the CJEU handed down its Ruiz Zambrano judgment, much discussion arose as to the exact meaning of this ruling. ${ }^{1}$ The subsequent Dereci judgment quashed a significant part of the promise that Ruiz Zambrano had shown, particularly with regard to the legal position of children. ${ }^{2}$ In response, scholars criticized the CJEU for not grounding the assessment of whether a child is forced to leave the territory of the Union in a (children's) rights approach. ${ }^{3}$ Six years after the Dereci judgment, the CJEu changed its course and merged the 'substance of rights' test with the normative framework of article 24 of the Charter in the case Chavez-Vilchez, therewith giving substantial meaning to children's EU citizenship status. ${ }^{4}$ This article zooms in on the landmark decisions Ruiz Zambrano and Chavez-Vilchez from a children's rights perspective. ${ }^{5}$ It submits that such a perspective is particularly helpful in understanding the conceptual underpinnings of these judgments and their broader significance. This broader significance is found in the legitimacy provided by these cases to the notion of children's rights and the Convention on the Right of the Child

1 Ruiz Zambrano, CJEU 8 March 2011, C-34/o9, EU:C:2011:277; See, for example, Peter Van Elsuwege, 'Shifting the Boundaries-European Union Citizenship and the Scope of Application of EU Law-Case No. C-34/o9, Gerardo Ruiz Zambrano v. Office National de l'Emploi', (2011) 38 Legal Issues of Econ Integration, 263; Kay Hailbronner and Daniel Thym, 'Case C-34/o9, Gerardo Ruiz Zambrano v. Office national de l'emploi (ONEm)', (2011) 48 Common Market L Rev, 1253; Anja Lansbergen and Nina Miller, 'Court of Justice of the European Union European Citizenship Rights in Internal Situations: An Ambiguous Revolution? Decision of 8 March 2011, Case C-34/og Gerardo Ruiz Zambrano v Office national de l'emploi (ONEM)', (2011) 7 European Constitutional Law Review, 287.

2 Dereci a.o., CJEU 15 November 2011, C-256/11, EU:C:2011:734; Alina Tryfonidou, 'Redefining the outer boundaries of EU law: the Zambrano, McCarthy and Dereci trilogy', (2012) 18 Eur Pub L, 493; Stanislas Adam and Peter Van Elsuwege, 'Citizenship rights and the federal balance between the European Union and its Member States: comment on Dereci', (2012) 37 European Law Review, 176.

3 Niamh Nic Shuibhne, 'Annotation of Case C-434/og McCarthy and Case C-256/11 Dereci', (2012) 49 Common Mrkt L Rev, 349, 379; Gareth Davies, 'The family rights of European children: expulsion of non-European parents', (2012), 3; Helen Stalford, Kathryn Hollingsworth and Stephen Gilmore, Rewriting children's rights judgments: From academic vision to new practice (Bloomsbury Publishing 2017), 529 .

4 Chavez-Vilchez, CJEU 10 May 2017, C133/15, EU:C:2017:354.

5 See for a discussion of other judgments on the 'substance of rights' test: Hester Kroeze, 'The Substance of Rights: New Pieces of the Ruiz Zambrano Puzzle', (2019) European Law Review, 238. 
(CRC). This legitimacy is particularly welcome in light of the under-theorization of children's rights. ${ }^{6}$

This article brings a number of discussions in children's rights literature and the cases of Ruiz Zambrano and Chavez-Vilchez together with the aim of illuminating and developing both theory and practice. In doing so, it underlines the importance for scholarly efforts aimed at developing children's rights theory to engage with judicial decision-making at the EU level and implementation at the national level and vice versa. The discussion of the Dutch national practice demonstrates implementation challenges that exist(ed) at the national level after the handing down of the Ruiz Zambrano and Chavez-Vilchez judgments and highlights the relevance of children's rights theory in understanding and overcoming these challenges. The article is divided into three parts with each part connecting the CJEU case law to children's rights scholarship and to the Dutch national practice. Part one discusses Ruiz Zambrano from the perspective of equal rights for children. Part two discusses Chavez-Vilchez from the perspective of distinct rights for children. Part three discusses the meaning of the child-specific factors listed in Chavez-Vilchez that must be taken into account and the possible role for developmental research in this regard.

Part I: Ruiz Zambrano and the Recognition of Children as Equal Right-Bearers

\subsection{A Short History of Children as Bearers of Rights}

Children's exclusion from the enjoyment of various fundamental rights is often connected to children's historical position in society and the history of fundamental rights. This history is characterised by unequal power positions and the relative invisibility of children. Nandy describes that many decades after the end of colonialism,

it has become obvious that the drive for mastery over men is not merely a by-product of a faulty political economy but also of a world view which believes in the absolute superiority of the human over the nonhuman and the subhuman, the masculine over the feminine, the adult over the

6 Lucinda Ferguson, 'Not Merely Rights for Children But Children's Rights: The Theory Gap and the Assumption of the Importance of Children's Rights', (2013) 21 The International Journal of Children's Rights, 177; Matias Cordero Arce, 'Maturing children's rights theory: From children, with children, of children', (2015) 23 The International Journal of Children's Rights, 283; Ann Quennerstedt, 'Children's rights research moving into the future - Challenges on the way forward', (2013) 21 The International Journal of Children's Rights, 233. 
child the historical over the ahistorical and the modern or progressive over the traditional of the savage. ${ }^{7}$

In discussing the importance of children's rights, Freeman claims that the values that these rights represent "were for most of history not discussed, indeed they were denigrated" in relation to children. ${ }^{8}$ This statement is illustrated by the fact that the position of children has been neglected in moral and political philosophy. Ferguson, for example, notes that Rawls did not devote any considerations to justice-based obligations to children in his A Theory of Justice. ${ }^{9}$

In more recent history - around the second half of the 19th century children are documented as becoming more visible in the legal realm but simultaneously confined to their own separate sphere. ${ }^{10}$ So-called 'welfare' or 'protection' laws such as compulsory education and custody regulation were adopted in most Anglo-Saxon and European states. ${ }^{11}$ In most nations, these laws were accompanied by some form of a 'best interests' principle. ${ }^{12}$ Views on childhood that would become dominant in developmental psychology, in particular, also emerged around this time and are deemed to have had a significant impact on the way in which such laws took shape and developed.13 The views on childhood underlying these disciplines were criticized for casting children as an object of adult socialization (the child as human becoming) and neglecting the child as subject in the here and now (the child as human being). In doing so, the child was "understood through adulthood" and defined by what $\mathrm{s} /$ he was not-yet or what $\mathrm{s} /$ he was lacking. ${ }^{14}$ This construction of childhood simultaneously allowed for the production of an idealized adulthood. This independent and autonomous adult tends to coincide with the

$7 \quad$ Ashis Nandy, Intimate enemy (Oxford University Press Oxford 1989).

8 Michael Freeman, 'The Value and Values of Children's Rights', in: The Human Rights of Children (Routledge 2016), 21.

9 Lucinda Ferguson, 'An Argument for Treating Children as a "Special Case", (2018) Philosophical Foundations of Children's and Family Law 227, 11.

10 Noam Peleg, The Child's Right to Development, doctoral thesis, UCL (University College London) 2013, 26.

11 Ibid. In the Netherlands, the Leerplichtwet (compulsory education) was enacted in 1900.

12 Ciara Smyth submitted that a possible explanation for the lack of discussion on the best interests principle is that all delegates were familiar with the principle from their national law (Ciara Mary Smyth, The common European asylum system and the rights of the child: an exploration of meaning and compliance ('s-Hertogenbosch: Uitgeverij Boxpress 2013), 24.

13 Wouter Vandenhole and others, Routledge International Handbook of Children's Rights Studies (Routledge 2015), 3.

14 Freeman, 'The Value and Values of Children's Rights', 26. 
envisioned right-bearer in liberal rights theory. ${ }^{15}$ In the words of Freeman, "the child lacks skills - is incompetent - whereas the adult is the finished product with full competency" ${ }^{16}$ For this reason, children were "generally not perceived as human rights holders". 17

The CRC has tied into this type of rights-thinking as it has been accredited with the introduction of a 'new' image of the child as an autonomous decisionmaker and bearer of rights. ${ }^{18}$ This does not necessarily imply that all fundamental rights ought apply to children as they do in relation to adults. According to Tobin, the recognition of children as rights-bearers requires courts to give:

(...) careful attention to the precise way in which the content of a child's right is to be interpreted so as to ensure their effective enjoyment. Steps must therefore be taken to ensure that the interpretative process accommodates the particular vulnerabilities of children as opposed to simply importing an adult-centric understanding as to the content of particular rights (emphasis added). ${ }^{19}$

This view on children as a subject of rights has also impacted on the meaning of the 'best interests' principle. The CRC promotes a rights based conception of best interests rather than a so-called welfare based conception..$^{20}$ By conceiving rights as a framework that informs the best interests assessment, this conception is envisioned as more 'objective' than the welfare conception and less susceptible to discretion-based, subjective and paternalistic decision-making that takes place externally from the child.

Even though the CRC has been ratified by all nations in the world - except for the United States of America (hereinafter: U.S.) - the field of children's rights scholarship is still in the process of maturation and the construction of children as right-bearers is still contested. The CRC and children's rights scholarship are both considered to suffer from under-theorization. Some scholars reject rights as a suitable framework for the regulation of the situation of

15 David Richards, 'Rights and autonomy', (1981) 92 Ethics, 3.

16 Freeman, 'The Value and Values of Children's Rights'.

17 Peleg, 'The Child's Right to Development' (diss), 28.

18 Didier Reynaert, Maria Bouverne-de-Bie and Stijn Vandevelde, 'A review of children's rights literature since the adoption of the United Nations Convention on the Rights of the Child, (2009) 16 Childhood, 518, 522-523.

19 John Tobin, 'Judging the Judges: Are They Adopting the Rights Approach in Matters Involving Children?', (2009) 33 Melbourne University Law Review, 586.

20 Ciara Mary Smyth, The common European asylum system and the rights of the child: an exploration of meaning and compliance ('s-Hertogenbosch: Uitgeverij Boxpress 2013), $23-26$. 
children and argue in favour of alternatives such an 'ethics of care' or 'obligations. ${ }^{21}$ Others oppose rights for children because they are considered a threat to parental rights. The rejection of children's rights for the latter reason is particularly present in U.S. discourse. Guggenheim, for example, states that pleas for the recognition of children's rights fail to appreciate "potential dangers associated with empowering state officials (judges)" to make decisions instead of parents. ${ }^{22}$ This threat is subsequently conceptualized as endangering the best interests of children as "parents are in a better position than anyone else to make the proper decisions for their children". ${ }^{23}$ Guggenheim's view resonates with a conception of 'the family' as a "site of exclusive and unfettered parental power" which a children's rights approach rejects. ${ }^{24}$ Tobin envisions the conception of 'the family' that underlies the CRC as follows:

the CRC offers what could be termed a collaborative or cooperative conception of the relationship between state and family as regards children's upbringing. This sits somewhere between the liberal individualist conception of the family, in which the state must not interfere with a family unless a child is at risk, and the collectivist conception, in which childrearing is under direct control of the community.

ARCHARD, 2004, 167-191 (emphasis added) ${ }^{25}$

A collaborative model thus allows for the state to bear duties towards the child that go beyond protecting him or her from erroneous harm.

The reasoning adopted by Guggenheim may give some insight into the reasons why the U.S. has not ratified the CRC. Despite not doing so, the 'new' way of thinking about children and their rights also sparked debates in the U.S. on the question what it means for children to be bearers of rights. The debates on the right not to be deported, which is stake for citizen children whose parents are threatened with deportation, are of particularly relevance for our purposes.

In the case RuizZambrano, the CJEU faced a situation that was rather specific and rare in the EU context, as none of the EU countries have unconditional ius

\footnotetext{
21 John William Tobin, 'Justifying Children's Rights', (2013) 21 International Journal of Children's Rights, 396.

22 Martin Guggenheim, What's wrong with children's rights (Harvard University Press 2009), $12 \mathrm{O}$.

23 Ibid.

24 Tobin, 'Judging the Judges: Are They Adopting the Rights Approach in Matters Involving Children?', 587 .

25 Tobin, 'Justifying Children's Rights', 425.
} 
soli policies in place (anymore). ${ }^{26}$ This means that the situation, where children are nationals of a Member States despite the fact that both parents do not have legal residency, is not a factual situation that courts often encounter. In countries with birth right citizenship policies in place - such as the U.S. - similar questions to the ones before the CJEU in Ruiz Zambrano have been debated and argued before the courts on numerous occasions. The body of case law and literature on this topic reveals the importance of the normative position that the CJEU took in the Ruiz Zambrano judgment, which on the judgment's 1oth anniversary ought to be highlighted.

\subsection{Ruiz Zambrano and the Recognition of the Child as Equal Bearer of the Right Not to Be Deported \\ 2.2.1 The De Facto Deportation of Citizen Children}

After the CJEU considered that the denial of a right of residency to the father of the Ruiz Zambrano children would force the children to leave the territory of the EU - therewith denying them the enjoyment of the substance of rights attached to the status of EU citizenship - commentators criticized the Court for not specifying which rights are attached to this status. ${ }^{27}$ The prohibition of the deportation of nationals is not one of the rights that is explicitly mentioned in the non-exhaustive list of rights laid down in article 20 TFEU. This right provides a particularly fruitful lens, however, in order to understand the Ruiz Zambrano judgment. For one because the language of "forced to leave the territory" resonates with the notion of deportation. Secondly, because any status that strives to be the "fundamental status" of nationals of Member States would necessarily include such a right. ${ }^{28}$

26 The Ruiz Zambrano children obtained the Belgian nationality on the basis of an act that aim to prevent statelessness. The children had lost their right to their parents' nationality after the parents had failed to register the children at the Colombian embassy. The Belgian policy has since been altered. See for more information on conditional ius soli policies in the EU: Maarten Peter Vink and Gerard-René De Groot, 'Citizenship policies in the European Union', (2016) Adjusting to a World in Motion: Trends in Global Migration and Migration Policy, 209.

27 See, for example: Dimitry Kochenov, 'The right to have what rights? EU citizenship in need of clarification', (2013) 19 European Law Journal, 502.

28 Article 3, 4th Additional Protocol of the European Convention on Human Rights (ECHR); Sandra Mantu, Expulsion of Own Nationals: What Implications for EU Citizenship, (2018) Nijmegen Migration Law Working Papers Series, 1; Dimitry Kochenov and Benedikt Pirker, 'Deporting the Citizens within the European Union: A Counter-Intuitive Trend in Case C-348/og, I. v. Oberbürgermeisterin der Stadt Remscheid', (2013) 19 Columbian Journal of European Law, 369, 376. 
The literature on the notion of de facto (also referred to as constructive) deportation of children in countries with birth right citizenship reveals many judgments where courts took an opposite approach to the one adopted by the CJEU in Ruiz Zambrano. In the Irish context for example, Mullally wrote about the considerations of Chief Justice Keane of the Irish Supreme Court. ${ }^{29}$ He considered that the right to reside within the state could not be vested in a minor until s/he was capable of exercising such a right. Mullally described how "the child's very dependency and vulnerability was invoked" to justify a denial of rights. ${ }^{30}$ In the landmark case Coleman vs the United States, the U.S. Supreme Court outlined the various justifications - given by lower courts for not giving meaning to the right of non-deportability during childhood. ${ }^{31} \mathrm{~A}$ number of these justifications boil down to the reasoning that the child's right to return to one's country of nationality when reaching the age of majority remains unaffected by the decision to deport a child's parents. ${ }^{32}$ Other arguments related to a fear of permitting "a wholesale avoidance of immigration laws if an alien were to be able to enter the country, have a child shortly thereafter, and prevent deportation" and the impact on the State's right to "determine the conditions under which an alien may enter and remain in the United States". ${ }^{33}$ Lastly, some courts considered the departure of the citizen child not "the necessary result of the government's actions". ${ }^{34}$ Some courts thus considered that children are not yet bearers of the right of non-deportability, others considered the consequences of interpreting this right in a meaningful and child-centred way unacceptable. The reasoning that the child could enjoy the right upon the age of majority illustrates an approach where an adult-centric understanding of the content of a rights is applied to children.

The criticism of Bhabha on these judicial approaches illuminates what is at stake for children in these situations and the significance of the approach adopted by the CJEU in Ruiz Zambrano. ${ }^{35}$ One of her criticisms relates primarily to the cases where an adult-centric understanding of the right to nondeportability was adopted. Such an approach - for example when the departure of the citizen child is not considered the result of governmental actions - does

29 Siobhan Mullally, "Citizen Children, "Impossible Subjects" and the Limits of Migrant Family Rights in Ireland', (2011) 1 European Human Rights Law Review, 43.

$30 \quad$ Ibid., 8.

31 Coleman v. United States, 454 F. Sup 2d 757, 766 (N.D. Ill. 2006).

32 Ibid., II. The Legal Sufficiency of Plaintiff's Allegations.

33 Ibid.

34 Ibid.

35 Jacqueline Bhabha, 'The "mere fortuity" of birth? Are children citizens?', (2004) 15 Differences: A Journal of Feminist Cultural Studies, 91. 
not claim that the minor does not hold the right but, instead, that it is given meaning in a sufficient manner. This approach accepts options such as having to remain in foster care in order to exercise citizenship rights, as an acceptable alternative. The extremity of such an option makes that citizenship loses "all real meaning". ${ }^{36}$ It constitutes a de facto suspension of rights.

A second criticism relates to the treatment of children as citizens and what it means for them to be excluded from this particular right. Bhabha points in this regard to the tension between citizenship as an inclusive status and the fact that children are excluded from important rights attached to citizenship such as the right to vote. She points out that "no other group of citizens has such partial access to the benefits of membership". ${ }^{37}$ Bhabha qualifies the guarantee of non-deportability as "arguably the most significant citizen-specific entitlement today". ${ }^{38}$ She adds "even treason cannot lead to deportability of a citizen". ${ }^{39}$ At the same time, decisions that affect where children grow up have a "pervasive impacts and lifelong consequences". ${ }^{40}$ Excluding children from the right of non-deportability, or rendering it effectively meaningless, is therefore particularly detrimental to the idea of meaningful citizenship for children.

Lastly, Bhabha connects the particular situation of de facto deportation to a larger asymmetry that is omnipresent in asylum and immigration law. This asymmetry lies in children's inability - in the context of US immigration law to secure derivative residency for parents while, at the same time, children are generally subsumed in parental asylum or residency claims. ${ }^{41}$ According the Bhabha, the asymmetry "assumes the absolute primacy of parental rather than child migration considerations" and is accepted as a "natural rather than a constructed asymmetry". 42 This focus on parents is reinforced by the fact that "the so-called 'abuse' of birth right citizenship to secure immigration advantages for undocumented or criminal alien parents is the prime contemporary concern."43

Rather than suspending citizenship rights during childhood, the CJEU made clear in Ruiz Zambrano that EU citizenship is destined to become the fundamental status of minor as well as adult member state nationals.

$\begin{array}{ll}36 & \text { Ibid., 10o. } \\ 37 & \text { Ibid., 93. } \\ 38 & \text { Ibid., 94. } \\ 39 & \text { Ibid. } \\ 40 & \text { Ibid., 95. } \\ 41 & \text { Ibid. } \\ 42 & \text { Ibid., 96. } \\ 43 & \text { Ibid., 99. }\end{array}$




\subsubsection{The Dominance of Legal Parent-Centrism in the ECHR Context}

Even though there are no longer any unconditional birth right citizenship policies in place in any of the EU member states, Bhabha's description of the values at stake, the pervasive asymmetry and abuse as a prime contemporary concern provides an equally relevant lens in the European context. Ruiz Zambrano can be seen as breaking with approaches with similar characteristics established in the case law of the ECtHR.

The ECtHR has never recognized the notion of de facto deportation under article 3 of the Fourth Protocol to the ECHR, which guarantees nondeportability to citizens. ${ }^{44}$ Additionally, its article 8 ECHR jurisprudence focusses on parents, rather than children, as right-bearers. The jurisprudence has been similarly and primarily shaped by parental considerations and with a focus on past ties rather than future ties. ${ }^{45}$ In decisions of the ECtHR's predecessor, the Commission, the residence rights derived from children's nationality were qualified as "theoretical" and the children themselves were cast as "children of unlawful overstayers". ${ }^{46}$ It was not until the Jeunesse judgment, which was ruled after Ruiz Zambrano, that the nationality of children became a factor of relevance within the balancing exercise that is required under article $8 \mathrm{ECHR}$ in cases that concern regularizations of parents. ${ }^{47}$ In this case, the Court considered "first and foremost" that, save for the mother, all members held the Dutch nationality. ${ }^{48}$

The Jeunesse judgment reproduced the overall logic that has shaped the application and interpretation of article 8 ECHR since the ECtHR's landmark decision Abdulaziz a.o., which is characterised by a focus on parental migration considerations and the state's sovereign right to control its borders. ${ }^{49}$ The ECtHR, however, simultaneously upset the asymmetry that underlies this logic, mainly through the notion of best interests. In Jeunesse, the Court first reiterated the guiding principles that place the choices made by parents - i.e. to establish or develop family life while aware of the precariousness of their residency - front and centre. It is settled case law that article 8 ECHR can only

44 Ellen Nissen, The rights of minor EU member state nationals wishing to enjoy family life with a Non-EU parent in their country of nationality. A study in the light of the UN Convention on the rights of the child (Oisterwijk: Wolf Legal Publishers 2013), 32.

Ibid.

46 Ibid., 35-36.

47 Jeunesse v. the Netherlands, ECtHR (GC) 3 October 2014, Appl. no. 9697/82.

48 Ibid., para 115.

49 For an extensive discussion of Abdulaziz a.o. see: Marie-Bénédicte Dembour, When humans become migrants: study of the European Court of Human Rights with an Inter-American counterpoint (Oxford University Press, USA 2015), 96. 
be violated in exceptional circumstances in cases where parents established or developed family life while aware of the precariousness of the residency of one of them. ${ }^{50}$ After doing so, the ECtHR also took steps in giving meaning to the best interests of the child in new ways.

Three conceptions of best interests that fit into the overarching welfare/ protection category - some more present and recognizable than others - have been pervasive in the Court's case law on regularization; the parental rights based conception, the abuse based conception, and the trump card conception. They are reflected in the dissenting opinion by judges Villiger, Mahoney and Silvis that accompanied the Jeunesse judgment. The dissenting opinion lays bare that the approach adopted by the Court in Jeunesse challenges these conceptions.

In their dissenting opinion, the judges compared the deportation of a parent to a parent's "chosen emigration from the Netherlands".51 They considered that if a child in such a situation does not wish to follow, there is no positive obligation on the state to intervene. This is the case, according to the judges, because it is "commonly understood that respect for family life implies that the best interests of the children are then considered to be best served by accepting the consequences of the (lawful) choices made by their parent." ${ }^{2}$ Similar to Guggenheim, the judges took the view that the conception of best interests adopted in Jeunesse poses a threat to parental rights and that it increases state power to intervene in the private sphere of the family. They considered it in the interests of children to protect them from such state power. In order to construct this argument, the judges thus drew on a liberal understanding of rights, where rights protect freedom of choice.

The ECtHR refrained in Jeunesse from adopting an abuse focussed approach as it had done in earlier judgments such as Butt and Kaplan. ${ }^{53}$ Such an approach is primarily guided by the risk of 'exploitation' of the situation of the children by the parent. In their dissenting opinion, the three judges submitted that assigning weight to the separate and individual interests of children would not be conducive "to the furtherance of the best interests of the children" because of the aforementioned risk of exploitation. ${ }^{54}$ Here, the risk of 'exploitation' does

\footnotetext{
$5^{\circ} \quad$ Jeunesse $v$. the Netherlands, para 108.

$5^{1}$ Jeunesse $v$. the Netherlands, joint dissenting opinion Judges Villiger, Mahoney and Silvis, para 9 .

$52 \quad$ Ibid., para 9 .

53 Butt v. Norway, ECtHR 4 December 2012, Appl. No. 47017/o9, para 79.; Kaplan a.o. v. Norway, ECtHR 24 July 2014, Appl. no. 32504/11, para 86.

54 Jeunesse $v$. the Netherlands, joint dissenting opinion Judges Villiger, Mahoney and Silvis, para 9 .
} 
not allude to the state's interest in the prevention of circumvention of immigration laws, but to the child's interests and the perceived incentive for parents to act contrary to these interests. The acts of having children and continuing precarious residency are thus cast as choices. These choices are subsequently conceived of as going against the best interests of children. For this reason, children deserve protection - by preventing them from being born - through the denial of their rights. The rejection of the Jeunesse approach to best interests - which assigns weight to the separate and individual interests of children - is thus justified in terms of best interests on the basis of normative and paternalistic views with regard to the question what is, or is not, in the best interests of children.

The trump card approach is characterised by an elevation of the best interests of children to the only and decisive consideration. There is an obvious incompatibility with such a conception and the entrenchment and recognition of the sovereign right of the state to control its borders in the Court's case law. In Jeunesse, the Court stated that the interests of children "alone" cannot be decisive but that they are of "paramount" importance and should be awarded "significant weight". ${ }^{5}$ In I.A.A., which was ruled after Jeunesse, the Court clarified the meaning of the word "paramount",

while the Court has held that the best interests of the child is a "paramount" consideration, cannot be a "trump card" which requires the admission of all children who would be better off living in a Contracting State. ${ }^{56}$

This conception and its problematization emerged in the context of regularizations of parents - albeit not explicitly - in the Nunez case. There, the dissenting judges reiterated a sentiment expressed by a Norwegian Supreme Court judge during the national proceedings. She took the view that if the expulsion in the case at hand was ruled disproportionate "it would be difficult to envisage when it would be possible to expel a foreign national who has a child with a person holding a residence permit". ${ }^{57}$ In Jeunesse, the dissenting judges did not make a similar claim but expressed concern about the "hot wash" that the margin of appreciation had undergone.

55 Jeunesse v. the Netherlands, para 109.

56 I.A.A. and Others v. the United Kingdom, ECtHR 31 March 2016, Appl. no. 2596o/13, para 46.

57 Nunez v. Norway, ECtHR 28 June 2011, Appl no. 55597/o9, Joint Dissenting Opinion of Judges Mijovic and de Gaetano, para 1. 
When viewing Ruiz Zambrano through the lens of children's free standing citizenship rights, the judgment's significance cannot be underestimated. It is a judgment that underscores the importance of recognizing children as equal citizens and bearers of fundamental rights by letting a child-centric perspective inform the content of the rights attached to EU citizenship. It strives towards substantive rather than formal equality, and challenges the pervasive asymmetry between the legal position of parents and children in immigration law, as a consequence of a preoccupation with parental rights and parental migration considerations. In doing so, it paved the way for the ECtHR to develop its article 8 ECHR case law in a similar direction.

The importance of this recognition becomes even more apparent when looking at the initial response of the Dutch legislator - upheld by the Council of State (the highest Dutch administrative court) - to the Ruiz Zambrano judgment. A response that led to the landmark judgment Chavez-Vilchez. It demonstrates that, the 'substance of rights' test was infused with a parental rights based conception of best interests.

\subsection{The Ruiz ZambranoJudgment in the Dutch Context}

The initial Dutch practice related to the 'substance of rights' test was fully shaped by a parental rights based conception of best interests. Children could only be regarded as forced to leave the territory of the Union when the EU national parent was proven fully unable to care for the child. ${ }^{58}$ This was accepted in circumstances where the EU parent was deceased, in prison or if his or her whereabouts were unknown. ${ }^{59}$ Outside of such factual circumstances, the test was fundamentally shaped by legal figures derived from custody and youth protection laws. Cases in which the influence of family law became apparent, concerned TCN parents who held single custody (eenhoofdig gezag). If the whereabouts of the EU parent were known, he or she was still assumed able to take on responsibility for the child. This assumption could only be rebutted by providing evidence that custody could not be shared with the EU parent. ${ }^{60}$ In cases of shared custody, the only case that was accepted in a Court ruling as meeting the threshold, concerned children who would have been placed into foster care after the deportation of the TCN father. ${ }^{61}$

$5^{8}$ Council of State, 2 September 2013, 201209027/1/V1, NL:RVS:2013:1147, para 3.2. Also see Van Eijken in this volume.

59 Council of State, 7 March 2012, 201105729/1/V1, NL:RVS:2012:BV8631; Council of State, 10 July 2012, 201103973/1/V1, [LJN: BX1345], NL:RVS:2012:BX1345.

6o Such as a family court judgment. See also Goos Cardol, 'Ruiz Zambrano vanuit familie- en jeugdrechtelijk perspectief', (2013) Asiel \& Migrantenrecht, 8.

61 Council of State, 2 September 2013, 201209027/1/V1, NL:RVS:2013:1147. 
The foregoing shows that in translating Ruiz Zambrano into the national legal order, the applicable norms were fundamentally shaped by the traditional realms of childhood regulation - namely, family and child protection laws rather than fundamental rights norms. ${ }^{62} \mathrm{~A}$ child was only considered forced to leave the territory of the Union if it was unambiguously proven that the State would have to assume the legal parental role if the child was to remain in the EU after deportation of the TCN parent. ${ }^{63}$ This resonates with the historical privatisation of childhood - where children are placed inside the 'private' sphere of 'the family' and outside of the domain of fundamental rights. It is the parent who is seen as responsible for ensuring the best interests of the child.

The pervasiveness of the privatization of childhood and the treatment of children as extensions of their parents in the field of immigration law underlines the importance of the Ruiz Zambrano and the subsequent Chavez-Vilchez ruling, as they provide children with rights that go beyond the bare minimum of protection. It also breaks with a conception of parental and children's rights as a zero sum game, where the latter necessarily comes at the cost of the former.

\section{Part II: From Ruiz-Zambrano to Chavez-Vilchez: \\ The Recognition of the Child as Both an Equal and Distinct Bearer of Fundamental Rights}

Having discussed the significance of the Ruiz Zambrano through the lens of children as equal bearers of fundamental rights in the first part of this article, the second part views Chavez-Vilchez in light of the recognition of children as distinct bearers of fundamental rights. Children are not only bearers of fundamental rights which apply to both children and adults. The Convention on the Rights of the Child grants them rights that apply exclusively to them. Part two dives into children's rights scholarship that explores the meaning of this category and the question whether granting children exclusive fundamental rights can be justified. The child as a distinct bearer of fundamental rights provides the conceptual lens through which the case Chavez-Vilchez is subsequently understood.

62 See for an approach shaped by fundamental rights norms Gareth Davies, The family rights of European children: expulsion of non-European parents, (2012) EUI RSCAS; [GLOBALCIT]; EUDo Citizenship Observatory, 10.

63 In line with Ruiz Zambrano, it was not deemed acceptable to envision, for example, extended family members to take on this role in order to enable children to enjoy the substance of rights attached to their EU citizenship status. 


\subsection{Children's Hybrid Legal Status}

The recognition of children as equal bearer of fundamental rights is primarily rooted in understandings of children as having interests and moral worth in the here and now (being) just like adults (sameness). Recent scholarship aims to capture the complexity of children's interests and children's legal position by reconciling various statuses; children as both human being and human becoming, both different from adults and the same, both citizen and child. Hollingsworth and Buss provide an illustration of an approach that aims to capture multiple statuses and sets of rights of the child in the context of juvenile justice. Buss asserts that merely applying the same (adult) constitutional rights to children - by adjusting for (perceived) empirical differences in capacity - fails to capture the difference in potential and therewith only tells "half the story of childhood" ${ }^{64}$ Hollingsworth similarly seeks to reconcile "the child's dual status and rights as offender and as child".65 The former status concerns rights that both adults and children have such as, in this particular context, the right to effective participation under article 6 ECHR. Hollingsworth conceptualizes the adaptation of the content of such a right in order to accommodate the particular qualities of childhood - by using child friendly language in the courtroom for example - as "simply a matter of achieving equality".66 It is more challenging, she contends, to theorize, understand and justify the latter status and category of rights. In order to understand the extent of this challenge it is helpful to explore Ferguson's work on the prioritization of the interests of children.

Ferguson is particularly interested in the question whether childhood as a socially constructed category - can justify the prioritization of children's interests. ${ }^{67}$ According to Ferguson, a practice that prioritizes children either grants them additional rights (i.e. rights that are not available to adults) or elevates their interests as a matter of law. The latter category means that children's interests are assigned weight or receive protection in a manner that supersedes other interests involved. This can, for example, be achieved by the establishment of a presumption in favour of the protection of certain interests. This can be contrasted against an approach where children's interests become decisive in individual cases, because of the factual circumstances in that particular case and the impact of a decision on the individual child. It is worthwhile to note

64 Emily Buss, 'What the law should (and should not) learn from child development research', (2009) 38 Hofstra L Rev, 13, 63 .

65 Kathryn Hollingsworth, 'Theorising children's rights in youth justice: the significance of autonomy and foundational rights', (2013) 76 The Modern Law Review, 1046, 1049.

$66 \quad$ Ibid., 1048.

67 Ferguson, 'An Argument for Treating Children as a "Special Case"', 15. 
that, according to Ferguson, prioritizing children's interests is not the same as these interests becoming a trump card. She relies on relocation cases - where one parent seeks permission from the family court to move to another (part of the) country - to show that the outcome that is regarded best for the child may not be chosen because of the detrimental impact on the particular parent concerned. It is then the vulnerability of the individual parent that can shift the balancing of interests. ${ }^{68}$ She, additionally, clarifies that conceptualisations of the vulnerability of children as a class - meaning all children below the age of eighteen - cannot serve as a guiding principle in individual cases but concerns a privileging of interests as a matter of law.

An approach that privileges children can only be justified - without falling foul of non-discrimination norms - by zooming in on something that makes childhood a distinct period of time to the degree that it qualifies as unique. While Ferguson primarily emphasizes the nature of children's vulnerability, others focus mainly on the extent of children's vulnerability. Ferguson locates this vulnerable nature, not only in the absence of certain (cognitive) capacities, but also in the "intrinsic goods of childhood". She mentions innocence, imagination, wonder and trust as examples of such goods. ${ }^{69}$ The unique extent of children's vulnerability lies in their reliance on adults. This reliance is not only of a physical - particularly in early childhood - and emotional nature, but also of an economic and legal nature (e.g. compulsory education; the right to work; the right to vote)..$^{70}$ It is evidenced by the fact that many laws treat children differently until the age of eighteen. ${ }^{71}$ Hollingsworth and Buss complement this understanding of the distinct qualities of childhood with a focus on children's potential, which they deem worthy of protection. As Hollingsworth puts it:

it is not that children are lacking something that adults possess, but that we wish to maximise their potential to become something more. ${ }^{72}$

Children's potential can to a large extent be captured by the notion of development. Various authors propose to infuse the notion of rights either with a general conception of human development or with a particular conception

\footnotetext{
$68 \quad$ Ibid, 44.

$69 \quad$ Ibid., 22.

70 Rosalind Dixon and Martha C. Nussbaum, 'Children's Rights and a Capabilities Approach: The Question of Special Priority', (2011) 97 Cornell L Rev, 549, 575-577.

71 Hollingsworth, 'Theorising children's rights in youth justice: the significance of autonomy and foundational rights', 1059 .

72 Ibid., 106o.
} 
of childhood development. ${ }^{73}$ Hollingsworth proposes a separate category of rights for children called foundational rights. These rights aim to protect childhood as a time for gathering the assets that are needed to enjoy "equally a fully (relational and capabilities based) autonomous adulthood." ${ }^{74}$

The foregoing highlights some characteristics of an approach that prioritizes the interests of children. Defining characteristics are not only the inclusion of exclusive rights for children, or a prioritization of the interests from the outset, but also the underlying conception of childhood as unique. This distinctness can be found in children's vulnerability and developmental potential. The next section will address the question to what extent such an approach can be observed in the case Chavez-Vilchez.

\subsection{Chavez-Vilchez: A Prioritization of Children's Interests?}

The approach adopted by the CJEU in Ruiz Zambrano is an archetypical example of an approach that refrains from applying an adult-centric understanding of a right (i.e. the right of citizens not to be forcefully removed from their country of nationality) to the situation of children and altering the scope in order to ensure the effective enjoyment of that right during childhood. The altered scope of the guarantee of non-deportability in order to ensure its effective enjoyment, as developed in Ruiz Zambrano, applied to children and adults alike (sameness) and can be seen as a form of (substantive) equalization rather than prioritization. The acknowledgment of children as citizens in the here and now does not necessarily capture other elements of childhood that might be worthy of protection. Chavez-Vilchez can be seen as an important step towards reconciling the statuses of the child as both human being and human becoming, and possibly as a prioritization of children's interests. ${ }^{75}$

73 Noam Peleg, The child's right to development (Cambridge University Press 2019), Chapter 7 and 8; Dixon and Nussbaum, 'Children's Rights and a Capabilities Approach:The Question of Special Priority'.

74 Hollingsworth, 'Theorising children's rights in youth justice: the significance of autonomy and foundational rights', 1049 .

75 The language of 'being' and 'becoming' is widely used in research on children: Barbara Arneil, 'Becoming versus being: A critical analysis of the child in liberal theory', in: David Archard, The Moral and Political Status of Children (Oxford University Press 2002), 70-93; Sarah C. White, 'Being, becoming and relationship: Conceptual challenges of a child rights approach in development', (2002) 14 Journal of International Development: The Journal of the Development Studies Association, 1095; Emma Uprichard, 'Children as "being and becomings": Children, childhood and temporality,' (2008) 22 Children \& society, 303; Jingyi Huang, 'Being and Becoming: the Implications of Different Conceptualizations of Children and Childhood in Education', (2019,) 10 Canadian Journal for New Scholars in Education/Revue canadienne des jeunes chercheures et chercheurs en éducation. 
In Chavez-Vilchez, the CJEU relied extensively on article 24 (2) of the Charter of Fundamental Rights of the EU (the Charter). ${ }^{76}$ The child's right to have one's best interests treated as a primary consideration - as laid down in article $24(2)$ of the Charter - is rooted in the particular nature of childhood rather than in the child's citizenship status. ${ }^{77}$ This is also evidenced by the child-specific factors listed by the CJEU that must be taken into account:

the age of the child, the child's physical and emotional development, the extent of his emotional ties both to the Union citizen parent and to the third-country national parent, and the risks which separation from the latter might entail for that child's equilibrium. ${ }^{78}$

The rights to have one's interests taken into account as a primary consideration is a right that only children have. It therefore seems to fit the definition as given by Ferguson of prioritization. Given that the right centres on the elevation of children's interests, however, it must elevate the interests of children as a matter of law in order to qualify. As discussed earlier, this can be contrasted against an approach where the interests of children take priority after examination of the factual circumstances in that particular case and the impact of a decision on the individual child. Ferguson demonstrates that this right also does not necessarily reveal an intention to prioritize children's interests. She points to conflicting sentiments expressed by the Committee on the Rights of the Child and in academic discourse in claiming that the best interests of the child principle is often discussed in a conceptually confusing manner or as a "means of avoiding devaluation of children" ${ }^{79}$ With regard to the former, she points to General Comment no. 14 (GC no. 14) on the best interests of the child in which the Committee on the rights of the Child states that children's interests should not be "considered on the same level as all other considerations". ${ }^{80}$ While this statement indicates a prioritization of children's interest, the Committee's subsequent statement that "[when] the interests of children are not highlighted,

Karl Hanson, Embracing the past: 'Been', 'being' and 'becoming' children (London: SAGE Publications 2017).

76 Chavez-Vilchez, para 70.

77 The explanation of the Charter reveals that Article 24 is based on the CRC, particularly Articles 3, 9, 12 and 13 CRC (2007/C 303/O2); The Charter provides in the preamble and Article $5^{2}$ paragraph 7 that the Court is to have due regard for this explanation.

78 Chavez-Vilchez, para 71.

79 Ferguson, 'An Argument for Treating Children as a "Special Case", 9.

8o Committee on the Rights of the Child, 'General comment no. 14 (2013) on the right of the child to have his or her best interests taken as a primary consideration (art. 3, para. 1)', 29 May 2013, CRC/C/GC/14, 10, under 37. 
they tend to be overlooked" indicates an underlying aim of rendering children visible or equalization. ${ }^{81}$ Regarding the latter, she cites Archard who took the view that without the best interests principle "we are in danger, as law was once, of ignoring the child, seeing it as having no distinct or special claim upon us". 82

An indication that Chavez-Vilchez indeed can be viewed as a manifestation of an aim to prioritize children's interests emerged in the case $K$.A. In this judgment, the CJEU translated the 'substance of rights' test in a different normative manner in relation to adults than in relation to children. Adults can only be deprived of the genuine enjoyment of the substance of rights in "exceptional cases" when there could be "no form of separation". ${ }^{33}$ This test is not mentioned in relation to minors. ${ }^{84}$ For this reason children, as a class, seem to be privileged from the outset rather than as a consequence of the way in which the notion of dependency plays out in particular factual situations and individual cases.

\subsection{A Trump Card Approach towards Chavez-Vilchez in the Dutch Context?}

The Dutch response to Chavez-Vilchez consists of two stages. The first response arrived not long after the judgment was handed down in May 2017. The new altered version - of the policy went into force on the first of July 2018. In a letter to parliament, immediately after the Chavez-Vilchez ruling, the Dutch Secretary of State took the position that a TCN parent of a Dutch child - from the moment of the ruling onwards - could only be denied residency when separation between the child and the third-country national (TCN) parent would not have any negative consequences for the child. ${ }^{85}$ Negative consequences were presumed if the TCN parent was taking on 'minimal' child care and child rearing tasks (marginale zorg-en/of opvoedingstaken). ${ }^{86}$ Consequently,

81 Lucinda Ferguson, 'Not merely rights for children but children's rights: The theory gap and the assumption of the importance of children's rights', (2013) 21 International Journal of Children's Rights, 177-208.

82 Ferguson, 'An Argument for Treating Children as a "Special Case", 9.

83 K.A. and Others, CJEU 8 May 2018 C-82/16, EU:C:2018:308, para 76.

84 The criterion as it applies to both children and adults is described as applying to "very specific situations" (Chavez-Vilchez, para 63,).

85 Kamerbrief over arrest Chavez-Vilchez (Letter to Parliament on the Chavez-Vilchez judgment), July 142017.

86 Mirjam den Besten and others, 'Een jaar na Chavez-Vilchez', 2018 (6-7) Asiel- en Migrantenrecht, 289 . 
9o percent of the applications were granted in the first year after the ruling. ${ }^{87}$ Rejections mainly concerned public order cases and situations where there was hardly any contact between parents and children. ${ }^{88}$ In the few judgments that were handed down in the latter type of cases, Courts similarly adopted an approach where the interests of children were the only consideration. In one case, for example, the Court considered that the immigration services had to demonstrate that the removal of a TCN parent would not pose any risk to the child's equilibrium. ${ }^{89}$ The first response thus adopted a trump card conception which considers the interests of child paramount.

The revised and more restrictive policy - implemented in 2018 - requires that TCN parents demonstrate they are taking on child care and child rearing tasks (hereinafter: care tasks) that go beyond the qualification 'minimal. ${ }^{90}$ Additionally, a TCN parent's identity must be established. ${ }^{91}$ This approach has not explicitly been conceptualised or justified in terms of 'best interests'. It seems that this approach can primarily be understood in light of the legal defensibility and practical workability of these conditions rather than from a particular conception of best interests. The explanations attached to the new policy focus more on the specific wording of the CJEU in Chavez-Vilchez than the initial response and on the question what practice can be considered permissible under EU law. It zooms in on paragraph 70 of the Chavez-Vilchez judgment which holds that states must determine "which parent is the primary carer of the child and whether there is in fact a relationship of dependency between the child and the third-country national parent". The policy change aimed to disentangle the two core elements of that paragraph; care and dependency. The child-specific factors are part of the dependency assessment. According to the Secretary of State, it cannot be inferred from the judgment that a child is at

87 Jocelyn Liu and others, Analyse Chavez-Vilchez, Rapport Ministerie van Justitie en Veiligheid, Immigratie- en Naturalisatiedienst, Directie Strategie en Uitvoeringsanalyse, 3o November 2018, www.ind.nl, Den Haag: IND 2018.

88 See Ellen Nissen and Tineke Strik, 'Het Chavez-Vilchez-arrest - Artikel 24 Handvest en het Ruiz Zambrano-criterium verenigd', in: $\mathrm{H}$ de Waele et al. (eds), Tien jaar EU-Grondrechtenhandvest in Nederland. Een impact assessment (Kluwer 2019), 203-224.

89 Regional Court The Hague, 25 November 2019, Awb 19/5017 and Awb 19/5018, NL:RBDHA:2019:14602.

9o Besluit van de Staatssecretaris van Justitie en Veiligheid van 21 juni 2018, nummer WBV 2018/4, houdende wijziging van de Vreemdelingencirculaire 2000, 36067; an application is rejected when a parent takes on 'minimal tasks' unless the contact between that parent and the child is frustrated by the other parent.

91 The Alien Circular states in section B 2.2 that valid border crossing document or a valid identity card must be submitted. If the TCN parent cannot comply with this, he must unambiguously prove his identity and nationality by other means. 
risk of being forced to leave the territory the Union when a parent is performing care and child-rearing tasks of a marginal character. ${ }^{92}$ The explanatory text of the new policy, additionally, claims that member states are free to ask proof of identity and nationality. The conditions are formulated as cumulative. This means that more than marginal care tasks and identity must be proven before the question of dependency - and the child-specific factors related to the notion of dependency - come into play. ${ }^{93}$ The evidentiary standard was heightened by a ruling of the Council of State with regard to the duty to investigate. ${ }^{94}$ According to the Council of State, the Secretary of State only has a duty to investigate in cases where it is proven that the TCN parent provides the day-to-day care for the child. The duty to investigate could involve holding a hearing or asking the Child Care and Protection Board to conduct investigations. ${ }^{95}$ As a permit will be granted in most cases where it is proven that the day-to-day care lies primarily with the TCN parent, the policy is designed with some help of the Council of State - in a way that allows for most cases to be decided without the immigration services having to conduct investigations.

To return to the central question of part two; can the way in which the Chavez-Vilchez ruling is implemented be understood as a prioritization of children's interests? The previous paragraph pointed out that the 'substance of rights' test is shaped differently in relation to children than it is in relation to adults. This difference is also observable in the way these tests have been translated into Dutch policy. There are no rules that govern situations of dependency in relation to adults. Two judgments were found where applications were denied because the Dutch nationals - born in 2000 and 2001 respectively - were no longer minors. ${ }^{96}$ With regard to the policy rules that govern the situation of children and the decision-making practice, it is useful to explore the extent to which children's interests seem to be protected from the outset by the categories it establishes.

First, we ought to examine the extent to which children are assumed dependent - in the sense that they would be forced to leave the territory of the Union if the TCN parent is forcefully removed - when the TCN parent is

\footnotetext{
92 Ibid., under J.

93 The challenges that these factors pose to the decision-making practice will be discussed in the third and last part of this article.

94 Council of State, 15 July 2019, 201808904/1/V1, NL:RVS:2019:2409, para 18.

95 Part three of this article will explore the role of the child-specific factors and investigations carried out by the Child Care and Protection Board.

96 Regional Court The Hague, 30 January 2020, AWB 19/2992 NL:RBDHA:2020:2389; Regional Court The Hague, 1 April 2020, AWB 19/7903 and AWB 19/7904 VK, NL:RBDHA:2020:4794.
} 
seen as providing more than marginal care tasks. In the analysis of the judgments ruled so far, seventeen cases were found where the immigration services took the position that the evidentiary standard of 'more than marginal care tasks' had not been met. ${ }^{97}$ Yet, no cases were found were this standard was met, but the decision was still denied due to lacking dependency. This observation allows for the inference that children - regardless of age or individual characteristics - are to a large extent presumed dependent once it is established that the ${ }^{T C N}$ parent provides more than marginal care tasks. ${ }^{98}$ Statements made by the immigration services during judicial proceedings also support this reading. ${ }^{99}$ This categorization arguably protects the interests of children as a class from the outset as no further evidence is needed to prove the additional condition, namely, 'dependency', in the individual case. It also established a burden of proof on the part of the State if it is to argue that there are particularly weighty state interests at stake in the individual case.

At the same time it must be noted that the creation of such a category comes at the cost of the individual assessment of the interests of the individual child in situations that do not fall into this category. When the evidentiary standard of 'more than marginal care' is not met, this establishes a - seemingly unrebuttable - presumption that the child is not forced to leave the territory of the EU. Consequently, the particular vulnerabilities of parents and/or children in such situations go unrecognized. The denial of an application filed by a mother who was limited in her ability to provide care due to cancer (treatment) - despite the circumstance that the mother and child seemed to be living together - illustrates this. ${ }^{100}$ In another case, the individual behavioural problems of the child concerned - such as concentration problems and difficulties regarding the regulation of anxieties - were not sufficient to change the outcome of the decision based on the care tasks criterion. ${ }^{101}$

It must, additionally, be noted that the evidentiary standards with regard to the question whether a TCN parent provides care tasks that go beyond the 'marginal' do not seem to be impacted by the circumstance that they

\footnotetext{
$97 \quad$ Last search conducted on October 3rd 2020.

98 It must be noted that no extensive analysis was conducted into to the ages of the children concerned. No cases were found, however, where the ages of the children were put forward by the immigration services as a relevant factor in evaluating the care tasks or relationship of dependency.

99 Regional Court The Hague, 24 April 2020, AWB 19/7843, NL:RBDHA:2020:3944, para 2.1.

100 Regional Court The Hague, 4 August 2020, AWB 2019/7994.

101 Regional Court The Hague, 9 April 2020 AWB 19/8708, AWB 19/8709 and AWB 19/9862, NL:RBDHA:2O20:3362.
} 
apply to minors. ${ }^{102}$ In one case, for example, the parents were in a relationship and shared custody but could not live together due to their financial circumstances. ${ }^{103}$ For this reason, mother and child were living with their (grand)mother. The father was staying nearby as to enable him to visit often. The evidence put forward consisted of - amongst other documents -70 pages of pictures (stretching over a time span of many years) and statements made by family, friends, a physician and school employees. The immigration services considered the pictures 'snapshots' and the additional evidence insufficiently objectifiable. This evaluation of the evidence arguably amounts to a de facto requirement for parent and child to live together, which not only defies the CJEU's judgment $K$.A., it also places children of low income families at a disadvantage, as Dutch citizens' social welfare (bijstand) is cut in situations of cohabitation with a person who does not have legal residency. ${ }^{104}$ The judgments also reveal that the evaluation of the evidence encompasses the factor time, despite this not being made explicit in the policy rules. In two cases, the immigration services denied the application because the evidence standard was not considered met for a long enough period of time. ${ }^{105}$

Such a high evidentiary standard resonates with the standards used throughout immigration law, irrespective of the question whether cases concern minors or adults. An alternative approach would be to - where the factual situation is unclear - to err on the side of the protection of the best interests of the child or to conduct further investigations into the facts.

The foregoing leads to the conclusion that the question of prioritization in the context of immigration is a multifaceted one. Norms that rely on a conception of childhood as a distinct time period that justifies the prioritization of the interests of children as a class can co-exist with norms that seemingly rely on opposite conceptions. The privilege of one category may, furthermore, function to the detriment of another. Such complexity in specific legal contexts warrants further exploration by children's rights scholars.

102 Due to limitations in the scope of this article an examination of the evidentiary standards with regard to the 'identity criterion' was not conducted.

103 The mother was still studying and the father was - in the absence of legal residency - not allowed to work.

104 See on this topic: Betty de Hart and Judith de Jong, 'Wat voor financiële problemen ondervinden legale en Nederlandse partners in gemengdestatusgezinnen?', Verblijfblog (http:// verblijfblog.nl/wat-voor-financiele-problemen-ondervinden-legale-en-nederlandse -partners-in-gemengdestatusgezinnen/).

105 Regional Court The Hague, 25 June 2020, AWB 19/5027, NL:RBDHA:2020:8737; Regional Court The Hague, 25 November 2020, AWB 19/5O17 and AWB 19/5018, NL:RBDHA: 2019:146o2. 


\section{Part III: The Child-Specific Factors of Chavez-Vilchez and Child Development Research}

In the previous sections, we examined the status of children as rights-bearers in relation to adults. The child-specific factors listed by the CJEU in Chavez-Vilchez position children in relation to other children. The influence of child developmental research - which is deemed to have had a big impact on the law regulating childhood and the application of the best interests principle - arguably becomes visible here. This section examines the meaning of the child-specific factors - in light of developmental psychology in particular - and the possible challenges that the CJEU judgment poses in this regard. These challenges may also illuminate the Dutch immigration services' struggle to incorporate these factors into their decision-making practices.

\subsection{The Child-Specific Factors and Child Development Research}

The child-specific factors mentioned by the CJEU in Chavez-Vilchez - in the context of article 24 Charter - show similarities with factors that are mentioned by the Committee in General Comment (GC) on the best interests of the child principle (No. 14). The GC, for example, addresses the question how to protect the child without neglecting the child as a "human being" and his or her evolving capacities:

There might be situations where "protection" factors affecting a child (e.g. which may imply limitation or restriction of rights) need to be assessed in relation to measures of "empowerment" (which implies full exercise of rights without restriction). In such situations, the age and maturity of the child should guide the balancing of the elements. The physical, emotional, cognitive and social development of the child should be taken into account to assess the level of maturity of the child. ${ }^{106}$

The notion of empowerment, and the age and physical and emotional development of (individual) children as a relevant consideration, particularly tie into debates on the child's right to have his or her wishes taken into account. ${ }^{107}$

106 Committee on the Rights of the Child, 'General comment no. 14 (2013) on the right of the child to have his or her best interests taken as a primary consideration (art. 3, para. 1)', UN Doc. CRC/C/GC/14, para. 83 .

107 Article 24 (1) Charter reads as follows: "Children shall have the right to such protection and care as is necessary for their well-being. They may express their views freely. Such views shall be taken into consideration on matters which concern them in accordance with their age and maturity." 
These debates appear most prominently in the context of family law and medical decision-making and to a lesser extent in the context of immigration. ${ }^{108}$ In the context of relocation cases - which are of particular relevance when discussing the impact of a separation between parent and child - Zafran states that "while age should be part of the decision, its effects are complex".109 She contends, however, that age should not just be taken into account in relation to the wishes of the child, but also as a factor in implementing the child's right to maintaining relationships. The younger the child, the less likely it is that meaningful relationship can be developed through infrequent visits.

The term 'equilibrium' - used by the CJEU in Chavez-Vilchez - and its meaning is anything but self-evident and does not appear in GC no. 14. The Merriam-Webster dictionary defines equilibrium as "a state of intellectual or emotional balance" or "a state of adjustment between opposing or divergent influences or elements". In relation to children the term can unquestionably be associated with Piaget, who is regarded as a pioneering force in the field of developmental psychology. ${ }^{110}$ His view on child development is widely regarded as having been very influential on the way in which the child is viewed in 'contemporary western' societies. ${ }^{111}$ His particular developmental psychological perspective can be characterized as rooted in a biological and genetic understanding of development and as relying on (and simultaneously producing) a conception of childhood that is universal. He has developed a cognitive theory of child development that divides childhood into four stages. Piaget initially conceptualized these stages as rigid, meaning that each child "with normally developing brains" was held to reach the next stage of development "under all circumstances at close to the same age". ${ }^{12}$ While at a later stage, context and child-specific variations in developmental pace gained prominence in his theory, development remained seen as driven by biology rather than by interaction with one's environment. ${ }^{113}$ The term 'equilibrium' refers to the moment

108 The debate is increasingly emerging in the context of immigration, see for example, Josine Krikke and Dana Baldinger, 'Hearing children in court proceedings in migration cases, towards recommendations', Liber Amicorum Elspeth Guild in: P. Minderhoud, S. Mantu \& K. Zwaan (Eds), Caught In Between Borders: Citizens, Migrants and Humans, Liber Amicorum in honour of prof. dr. Elspeth Guild, Tilburg: Wolf Legal Publishers 2019, 199-208.

109 Ruth Zafran, 'Children's Rights as Relational Rights: The Case of Relocation', (2010) 18 Journal of Gender, Social Policy \& the Law 1, 211.

110 Harry Beilin, 'Piaget's enduring contribution to developmental psychology', (1992) 28 Developmental psychology 191, 1 .

111 Vandenhole and others, Routledge International Handbook of Children's Rights Studies, 64.

112 Buss, 'What the law should (and should not) learn from child development research', 49.

113 Ibid. 
when a child reaches a new cognitive stage of development where a balance occurs between what a child perceives and what s/he is able to explain. ${ }^{114}$ As Beauchamp puts it: "Piaget conceived equilibration as an ongoing process that refines and transforms mental structures, constituting the basis of cognitive development". ${ }^{115}$ While Piaget remains highly influential, subsequent theories tend to move away from such fixed conceptions of stages of development. Buss contrasts Piaget's theory against those of Vygotsky and Erikson. She describes the former as having developed a "socio-cultural" theory of child development which focuses on the role of adults and peers in facilitating development and the latter as pioneering the study of identity formation which he considered "the primary developmental project of adolescence".116

While these theorists build on - and relate to - each other's work, the term equilibrium in relation to children is primarily associated with Piaget's theory. What does this mean for our interpretation of the CJEU's use of the term? Since his theory is generally presented as placing biology in the developmental driver's seat, it appears to sit ill with the Court's overall recognition of the importance of parental relationships for children. Additionally, while the term equilibrium - and to a certain extent the Court's reference to age as a factor of relevance - seems to point in the direction of Piaget's understanding of development and to general knowledge related to particular age categories rather than individual children, the other factors mentioned point in the direction of an individualized assessment. This need for individualized assessment is underlined by the Court's reference to the individual child's ties to both parents and when viewing the criteria in relation to each other. Lastly, the term "emotional" seems to resonate with Erikson's understanding of development as his theory is described by Buss as focusing on "emotional growth".117

It is most persuasive to understand the child-specific factors as requiring general knowledge in relation to age coupled with an individualised assessment. Such an approach can be found in the ECtHR's case Nunez v. Norway. The Court's reasoning in this case can be traced back to the minority judgment of the Norwegian Supreme Court. One of the judges - whose reasoning was endorsed by the minority - drew on General Comment no. 7 of the Committee on the Rights of the child (the Committee) which states that:

\footnotetext{
114 Saul McLeod, 'Jean Piaget's theory of cognitive development', (2018) Simply psychology, 1. 115 Anne S. Beauchamp, 'Cognitive equilibrium', Encyclopcedia Britannica, at: https://www .britannica.com/science/cognitive-equilibrium.

116 Buss, 'What the law should (and should not) learn from child development research', 5 o.

117 Ibid., 51.
} 
Young children are especially vulnerable to adverse consequences of separations because of their physical dependence on and emotional attachment to their parents/primary caregivers. They are also less able to comprehend the circumstances of any separation. Situations which are most likely to impact negatively on young children include ... situations where children experience disrupted relationships (including enforced separations), ... (emphasis added). ${ }^{118}$

On the basis of this general age-based knowledge, she subsequently proceeded to examine the ages and situations of the children effected by the decision. The ECtHR referred to the minority judgment on multiple occasions ${ }^{119}$ and considered "the disruption and stress that the children had already experienced" a relevant exceptional circumstance. ${ }^{120}$ Their ages (six years, ten months and five years, four months respectively), ${ }^{121}$ and the circumstance that these particular children had endured a separation from their mother before, became of decisive importance. Lastly, the Nunez case may serve as an inspiration with regard to the question how the term 'equilibrium' ought to be understood because of the reference to comprehension. A similar emphasis on, and relevance of, children's ability to understand the circumstances of a separation also appears in the case law of the German Constitutional Court with regard to the question whether a parent can be denied regularization and referred to the visa procedure. ${ }^{122}$

Besides a better understanding of the terms used by the Court, what can legal scholars additionally take from the foregoing? Buss describes a development "over the course of the twentieth century" where child development research and law took an increasing interest in one another. ${ }^{123}$ This development somehow seems to have passed over the field of migration law. Seeing as the terms used by the Court can only be understood by adopting an interdisciplinary approach, it is submitted that the Chavez-Vilchez ruling must be

\footnotetext{
118 Nunez $v$. Norway, para 24.

119 Nunez v. Norway, paras 79, 80, 81, 83.

$120 \quad$ Nunez v. Norway, para 84.

121 It is very rare for the ages of children to appear in judgments with such precision.

122 "Even a temporary separation cannot be considered reasonable if the court does not develop an idea of which period of separation it considers reasonable. The consequences of a temporary separation have a high weight, arguing against the termination of residence, especially if a very young child is affected, who may not be able to understand the only temporary nature of a spatial separation and who quickly experiences this as a permanent loss (see BVerfG, decision of the 2nd Chamber of the Second Senate of January 23, 2006 - 2 BvR 1935/o5-, NVwZ 2006, $682<683>$ )."

123 Buss, 'What the law should (and should not) learn from child development research', 13.
} 
considered an invitation for migration law to engage with child development research. Another indicator that points to the importance of developmental research is the CJEU's use of the word 'risk'. Individualised assessments of a child's developmental process and wellbeing are in fact risks assessments. ${ }^{124}$ For this reason, it may be useful to look at the development described by Buss in other fields of law and what lessons we might draw from experiences with reconciling law and child development research.

\subsection{The Relationship between Law and Child Development Research}

When looking at the literature on the relationship between law and child development research two observations can be made. Firstly, a consensus that the law should take knowledge derived from child development research into account. It is conventional wisdom among children's rights scholars, according to Buss, that law should take account of the "growing body of science and social science". 125 This can be understood in light of the nature of the best interests of the child principle, which is notorious for its open-endedness and susceptibility to biased and subjective decision-making. ${ }^{126}$ Tobin, for example, regards engagement with social sciences as a defining feature of a children's rights approach and suggests that reliance on social sciences is one way of countering this susceptibility. ${ }^{127}$ This benefit of the use of social sciences in cases concerning children has also been identified as a possible pitfall. This brings us to the second observation; a clear sentiment emerges from the literature that certain risks are involved in taking this knowledge into account, such as the hazard of too much deference being given to such knowledge. Scholarly warnings in this regard can particularly be observed in the context of juvenile criminal law and family law. In the context of family law, for example, Huntington states that "using empirical evidence focuses attention on the outcomes of legal rules, discouraging a debate about contested and competing values. Reliance on empirical evidence overlays a veneer of neutrality on

124 Margrite Kalverboer and others, 'The best interests of the child in cases of migration: Assessing and determining the best interests of the child in migration procedures', (2017) International Journal of Children's Rights 25/1, 114-139. The authors state that "in the assessment of the best interests of children who are forcibly migrated, special attention has to be given to risk factors (...)". The word 'risk' appears 20 times in the contribution.

125 Buss, 'What the law should (and should not) learn from child development research', 13.

126 Mark Klaassen and Peter Rodrigues, 'The best interests of the child in EU family reunification law: A plea for more guidance on the role of article 24 (2) charter', (2017) 19 European Journal of Migration, 191, 194.

127 Tobin, 'Judging the Judges: Are They Adopting the Rights Approach in Matters Involving Children?', 591-592. 
normative judgments". ${ }^{128}$ Additionally, it is questioned to what extent reliance on social sciences is able to remedy bias and subjective decision-making as research is also susceptible to manipulation to being employed to serve certain agendas. ${ }^{129}$ Buss points to a danger of courts litigants and scholars picking and choosing among the sources "to find the research that supports their own predilections". ${ }^{130}$ Lastly, there may be a mismatch between the knowledge that is required by the law and the knowledge that social sciences can offer. For example, while the law needs stability and legitimacy, debates in the social sciences are ongoing a constantly evolving, particularly in relatively young fields of science. ${ }^{131}$ Buss and Huntington both touch on the issue that law tends to rely on fixed categories, while scientific knowledge does not lend itself for the justification, realisation of hard lines and generalizations that hold true for all individuals. ${ }^{132}$

There is thus a clear tension between the consensus on the need for interdisciplinary approaches towards decision-making of children and the risks and difficulties involved in doing so. How to go about such a challenging exercise? It is submitted that rather than using social sciences for clear answers, it ought to inform and feed into decision-making without it taking the driver's seat. ${ }^{133}$ Huntington takes the view that engagement with developmental sciences ought to proceed with caution and with an appreciation for what tentative conclusion can be drawn, for what is unknown and for what may be ill-understood by non-experts. ${ }^{134}$ The next section will explore what answers to important questions related to the role of social sciences can be found in the work of the Committee on the Rights of the Child.

\subsection{The Committee on the Rights of Child, the Right to Development and Child Development Research}

When talking about children's rights and about article 24 of the Charter of Fundamental Rights, the CRC is an inescapable point of reference. ${ }^{135}$ The

\footnotetext{
128 Clare Huntington, 'The Empirical Turn in Family Law' (2018) 118 Columbia Law Review 227.

129 Ibid., 56.

130 Ibid., 36.

131 Clare Huntington, 'Neuroscience and the child welfare system' (2012) 21 JL \& Pol'y 37, 281.

132 Buss, 'What the law should (and should not) learn from child development research', 37; Huntington, 'Neuroscience and the child welfare system', 52.

133 Buss, 'What the law should (and should not) learn from child development research', 15; Peleg, The child's right to development, 202; Huntington, 'The Empirical Turn in Family Law', 234.

134 Huntington, 'The Empirical Turn in Family Law', 54.

135 Explanations Relating to the Charter of Fundamental Rights (2007/C 303/O2); the Charter provides in the preamble and Article $5^{2}$ paragraph 7 that the Court is to have due regard for this explanation.
} 
Committee provides authoritative guidance on the interpretation of the Convention. In GC No. 14 the Committee speaks on multiple occasions about a "multidisciplinary team" that should be involved in the best interests assessment. The "formal assessment process" should be carried out by a professional trained in "child psychology, child development or other relevant human and social development fields" while "the assessment of the consequences of alternative solutions must be based on general knowledge (i.e. in the areas of law, sociology, education, social work, psychology, health, etc.)".136 The notion of development is omnipresent in the CRC. In G C No. 5 , the Committee identified domains of development and qualified it as a guiding principle:

The Committee expects States to interpret "development" in its broadest sense as a holistic concept, embracing the child's physical, mental, spiritual, moral, psychological and social development. Implementation measures should be aimed at achieving the optimal development for all children. ${ }^{137}$

In five articles, the term 'development' is mentioned. ${ }^{138}$ Article $6 \mathrm{C}$ C lays down a right to life, survival and development. Peleg's analysis of the Committee's interpretation of the right to development showed, however, that there was not "a single occasion when the Committee clarifies what the right to development stands for; what it protects (for example, the process of development, the outcome of it, or perhaps both); what its aims are". ${ }^{139}$ He takes the position that the ambiguity that surrounds article $6 \mathrm{CRC}$ can be explained by the absence of the notion of 'child development' in the legal discipline and the lack of engagement of the discipline with its meaning. ${ }^{140}$

In his PhD research of 2013, Peleg conducted nine interviews with (former) members of the Committee. The interviews revealed what Peleg calls 'the discipline gap'; people from various professional background may not share the same understanding of development. One quote from a (former) member in particular sheds light on the troubles that the Committee is facing when it

136 Committee on the Rights of the Child, 'General comment no. 14 (2013) on the right of the child to have his or her best interests taken as a primary consideration (art. 3, para. 1)', 29 May 2013, CRC/C/GC/14, 19, under 94-95.

137 Committee on the Rights of the Child (CRC), 'General comment no. 5 (2003): General measures of implementation of the Convention on the Rights of the Child', 27 November 2003, $\mathrm{CRC} / \mathrm{GC} / 2003 / 5,4$, under 12 .

138 Articles 18, 23, 27, 29 and 32.

139 Peleg, The child's right to development, 140.

140 Ibid., 199. 
comes to the meaning of development and, according to Peleg, summarizes the Committee's approach:

I understand development to have several meanings, which vary depending on the context. For those who are coming from a psychological background, development has a certain meaning. But for those who are coming from the international community, people from the UNDP for example, development has a different meaning. They hold a different conception of development. This gap might be the reason for neglecting this component of Article 6. I think that the confusion is still there. Until now, we were not truthful about the fact that there is confusion, and we never asked what does the right to development in Article 6 mean. ${ }^{141}$

Some (former) members of the Committee told Peleg that the Committee assumes that 'development' "will happen on its own, as a result of protection of other rights". ${ }^{42}$ All members viewed the protection of children's development as the aim of the Convention. ${ }^{143}$ This sentiment is also reflected in GC no. 14 on the best interests of the Child which states that all the rights in the Convention are in the best interests of the child, that these rights cannot be overridden by an adult's judgment of a child's best interest or a negative interpretation of the child's best interests. ${ }^{144}$ In turn, the concept of the best interests of the child aims to ensure the holistic development of the child. ${ }^{145}$ Peleg's argues that this dominant 'holistic' conception of development resonates primarily with a understanding of development that is rooted in developmental psychology and neglects or even ignores the fundamental rights aspects. ${ }^{146}$

The foregoing, again, highlights a consensus on the need for multidisciplinary perspectives but that the issue of how to reconcile knowledge from the social sciences with a legal understanding of child development is - even for the Committee on the Rights of the Child - a challenging matter.

\footnotetext{
141 Ibid., 154 .

142 Ibid., 165.

143 Ibid.

144 Committee on the Rights of the Child, 'General comment no. 14 (2013) on the right of the child to have his or her best interests taken as a primary consideration (art. 3, para. 1)', 29 May 2013, CRC/C/GC/14, 3, under 4.

145 Ibid.

146 Peleg, The child's right to development, 172.
} 


\subsection{The Use of Expert Knowledge in Article 20 TFEU Cases concerning Minors in the Dutch Context}

One actor that is widely regarded as having expert knowledge on children and that plays a role of significance in the context of article 20 TFEU is the Child Care and Protection Board (the agency that investigates "families with parenting problems"; hereinafter: the Board). The Board's role in immigration procedures concerning children increased significantly after a project was initiated in 2015 which aimed to intensify the cooperation between the Board, the immigration services and the governmental body tasked with facilitating returns. This cooperation concerns, besides article 20 TFEU cases, situations such as Dublin transfers and situations where the children concerned are under the supervision of the State.

During a 'Chavez-Vilchez pilot', the Board was asked in 25 cases - where doubts existed as to the question whether the TCN parents was taking on minimal child-rearing tasks - to investigate whether a relationship of dependency existed. ${ }^{147}$ This pilot transitioned into a cooperation of a broader and more permanent nature. On the 22nd of June 2020, a protocol of action in the context of so-called 'Chavez-Vilchez investigations' by the Board was published. ${ }^{148}$ It states that the immigration services can ask the Board to conduct investigations in three specific situations. The first concerns situations where suspicion has arisen that that care provided by the TCN parents is "damaging to the development of the child". This could be the case when the TCN parent is suffering from addiction or suspected of domestic violence. The second category of situation arises when the IND is experiencing difficulty to establish the facts. This could be the case when parents are contradicting each other. The last situation mentioned occurs when a judge rules that investigations ought to be conducted. Strikingly, the protocol does not make mention of investigations into the child-specific factors mentioned in Chavez-Vilchez, on which the Child Care and Protection Board is presumably particularly knowledgeable. ${ }^{149}$ This points to a reluctance on the part of the immigration services to defer to the knowledge of the Board.

\footnotetext{
147 Jocelyn Liu and others, Analyse Chavez-Vilchez, Rapport Ministerie van Justitie en Veiligheid, Immigratie- en Naturalisatiedienst, Directie Strategie en Uitvoeringsanalyse, 30 November 2018, www.ind.nl, Den Haag: IND 2018.

148 https://www.rijksoverheid.nl/documenten/rapporten/2020/o6/22/tk-bijlage-3a-proces beschrijving-chavez-rvdk-ind.

149 The specific questions asked to the Board - such as, 'what is the living situation?' - also seem to be mainly of a factual and descriptive nature. See: https://www .rijksoverheid.nl/documenten/rapporten/2020/06/22/tk-bijlage-3b-format-onderzoek -raad-voor-de-kinderbescherming.
} 
How this reluctance can be best understood is of a speculative nature, but two factors likely play a role. Firstly, in hardly any of the 25 cases did the Board conclude that there was no relationship of dependency between parent and child. ${ }^{150}$ One judgment is particularly helpful in understanding this. The case concerned a father who - after a few short and sporadic moments of contact during the first years of her life - had only spoken to his daughter over the phone in recent years. ${ }^{151}$ The Board considered that there was a relationship of dependency because of the "existential loyalty" that children generally feel towards their biological parents. The current policy design allowed for the decision-making practice to steer away from the risk of having to defer to such broad conceptions of dependency. Secondly, in its investigations, the Board relies extensively on information of so-called 'informants' such as family members or physicians to conduct its investigations and draw its conclusions. As we have seen in the previous section, this is the type of information that is generally evaluated by the immigration services as 'insufficiently objectifiable'.

In none of the recent judgments in which the current policy rules were applied, did submissions by experts - such as remedial educationalist or behavioral scientists - change the outcome of the case. In one of the cases, the immigration services had taken the position that no risks to the equilibrium of the child appeared to be present, despite the fact that a report had been put forward in which a psychologist concluded that deportation of the TCN father concerned would have "serious emotionally disruptive consequences" for all members of the family. ${ }^{152}$ The applicants, additionally, rebutted the statement of the immigration services by claiming that they lack expertise on this matter. The Regional Court did not follow this argument and ruled against the applicants without devoting any discussion on the role of expert knowledge in this context.

The foregoing underscores the difficulty - touched upon in the literature discussion - for policy makers to incorporate and respect knowledge on child development without (giving into fears of) losing control over the degree of deference shown to expert knowledge.

150 Jocelyn Liu and others, Analyse Chavez-Vilchez, Rapport Ministerie van Justitie en Veiligheid, Immigratie- en Naturalisatiedienst, Directie Strategie en Uitvoeringsanalyse, 30 November 2018, www.ind.nl, Den Haag: IND 2018, 4.

$15^{1}$ Regional Court The Hague, 20 December 2018, AWB 18 / 4509, NL:RBDHA:2018:15832.

$15^{2}$ Regional Court The Hague, 28 August 2020, AWB 19/9943, NL:RBDHA:2020:8811. 


\section{$5 \quad$ Concluding Remarks}

This article analysed the Ruiz Zambrano and Chavez-Vilchez judgments from a children's rights perspective. The lens employed - grounded in the CRC enhanced our understanding of the judicial approach chosen by the CJEU. The fruitfulness of this approach indicates that the CJEU subscribed to in the words of Tobin - a conceptual 'model of children's rights', despite the fact that other paths could have been followed. ${ }^{153}$ The observed space for choice strengthens the claim often made in children's rights literature that judges usually - to varying degrees - have the possibility to defensibly push judicial boundaries by adopting a children's rights model. ${ }^{154}$ Walking the tightrope of judicial activism is arguably necessary in order to give substance and meaning to children's rights. ${ }^{155} \mathrm{~A}$ start was made with envisioning a future where empirical knowledge on childhood feeds into decision-making on article 20 TFEU cases. Such a development could impact immigration law in a broader manner. It is a vital academic task to keep the interdisciplinary dialogue between children's rights theory, the judiciary and the decision-making practice going.

153 Tobin, 'Judging the Judges: Are They Adopting the Rights Approach in Matters Involving Children?'.

154 Ibid., 620; Stalford, Hollingsworth and Gilmore, Rewriting children's rights judgments: From academic vision to new practice (Hart Publishing 2017); Caroline Joanna Forder, Rechterlijke creativiteit en de rechten van het kind (Boom Juridische uitgevers 2013).

155 Peter Van Elsuwege and Dimitry Kochenov, 'On the limits of judicial intervention: EU citizenship and family reunification rights', (2011) 13 European Journal of Migration and Law, $443-466$ at 465 . 